\title{
KANATALOUDEN TEKNILLINEN JA TALOUDELLINEN KEHITYS SIIPIKARJANHOITAJAIN L.IITON KIRJANPITOIMINNAN TULOSTEN VALOSSA
}

\author{
N. WESTERMARCK \\ Helsingin yliopiston maanviljelystalouden laitos
}

Saapunut 25. 6. 1960

Kirjanpitoon perustuva kanatalouden ja lähinnä kananmunantuotannon kannattavuustutkimus otettiin Siipikarjanhoitajain Liiton työohjelmaan vuonna 1932, ja kirjanpitotoiminta aloitettiin saman vuoden marraskuun ensimmäisenä päivänä. Kirjanpito on sen jälkeen jatkunut, joskin se oli keskeytyksissä sodan aikana ja eräinä muinakin vuosina 1930-luvulla. Toiminta herätettiin jälleen henkiin vuoden 1948 syksyllä, minkä jälkeen se on keskeytymättä jatkunut. Toiminta on nimenomaan keskittynyt varsinaisiin tuotantokanaloihin, jotka ostavat tai itse haudottavat poikasensa, mutta eivät sanottavasti myy siitosainesta. Koska haudonnat 1950-luvulla ovat siirtyneet yhä aikaisemmiksi, muutettiin vuonna 1951 kirjanpitovuosi alkavaksi 1. päivästä lokakuuta. Mainittu ajankohta sopiikin parhaiten kanatalouden kirjanpidon alkamisen ajankohdaksi, koska tällöin alkaa uusi tuotantokausi nuorikoiden ollessa munintakypsiä. Myös vuosittain karsittavat eläimet on siihen mennessä suurimmaksi osaksi poistettu.

Joskaan tässä yhteydessä ei ole mahdollista yksityiskohdittain selvittää tulosten esittämisessä käytettyjä perusteita, on kuitenkin syytä mainita eräitä kohtia. Kokonaistuottoon sisältyvät sekä myydyt että kotitaloudessa käytetyt ruokamunat, samoin myydyt poikaset sekä kotitaloudessa käytetyt ja myydyt teuraseläimet. Kokonaistuottoon sisältyy myös lanta. Sen arvo on laskettu ravinteitten hintatason perusteella. Koska on kysymys varsinaisista tuotantokanoista, muodostaa munantuotoksen arvo pääosan kokonaistuotosta. Tämä osuus on 1950-luvulla ollut keskimäärin $91 \%$ kokonaistuotosta. Munantuotoksesta on markkinoitu $93 \%$, loppuosa on käytetty kotitaloudessa. Kun seuraavassa mainitaan 1950-luku, siihen sisältyy myös kirjanpitovuosi 1. 11. 48—31. 10. 49, josta käytetään mainintaa 1949. Myös muiden kirjanpitovuosien suhteen menetellään niin, että ne mainitaan sen vuosiluvun perusteella, joka käsittää pääosan toimintavuodesta. Kotitaloudessa käytettyjen ruokamunien arvo on laskettu ruokamunien tilityshintojen mukaan niitä kuitenkin harkinnanvaraisesti jonkin verran alentaen. Poikastuotto on 1950- 
luvulla ollut vain noin $2 \%$ kokonaistuotosta, mikä osoittaa, että kirjanpitotoimintaan osallistuneet kanataloudet ovat todella varsinaisia kananmunia tuottavia yrityksiä. Käsitteeseen poikastuotto ei sisälly omaa tarvetta varten kasvatettujen poikasten arvo, joka esiintyy eläinarvon tilivuoden aikana tapahtuneena lisäyksenä.

Kustannusten määrittämisestä on mainittava seuraavaa. Ensinnäkin on todettava, että käsitteellä tuotantokustannus tarkoitetaan kaikkia kustannuksia yhteensä. Tuotantokustannukseen sisältyvät siten myös yrittäjäperheen oman työn arvo ja korkokustannus siinäkin tapauksessa, että mitään korkoja ei ole maksettu, jolloin se muodostuu korkovaatimuksesta. Korkokustannus on 1950-luvulla laskettu $5 \%$ :n mukaan, aikaisempina vuosina $7 \%$ :n mukaan. Työkustannus on siten laskettu, että työn menekki on saatu kirjanpidosta, kun taas työtunnin hinnan perusteena on käytetty vahvistettuja normipalkkoja, joskin niitä on harkinnanvaraisesti jonkin verran alennettu. Tätä menettelyä on perusteltu sillä, että kanataloudessa usein työskentelee henkilöitä, joiden työkyky ei ole aivan täysipainoinen. Mikäli palkkatyövoimaa on käytetty, on työ hinnoiteltu todella maksettujen palkkojen mukaan. Vielä mainittakoon, että näin saatuun ruumiillisen työn kustannukseen on lisätty $10 \%$ johtotyön osuudeksi. Rehun käyttö kanaa kohti vuodessa on laskettu siten, että kokonaisrehun kulutuksesta on vähennetty poikasten normien mukainen rehun kulutus ja jäännös on jaettu täysikasvuisten kanojen lukumäärällä. Samoin on menetelty laskettaessa rehun kulutusta munakiloa kohti. Kustannuksiin sisältyy siten erikseen mainittuna täysikasvuisten kanojen rehukustannus ja poikaskasvatuksen vaatima rehukustannus.

Rakennusten arvioinnissa on käytetty perustana jälleenhankinta-arvoa ja siitä johdettua nykyarvoa rakennusten ikä ja arvioitu kestoaika huomioon ottaen. Jälleenhankinta-arvo lattia-alan $\mathrm{m}^{2}$ :ä kohti on sidottu rakennuskustannusindeksiin ja laskettu tiettyjen normilukujen mukaan, koska ei ole mahdollista saada tietoja todellisista rakentamiskustannuksista. Vuotuinen rakennuskustannus koostuu poistosta, kunnossapidosta ja vakuutusmaksuista.

Taulukoista ilmenevät kanatalouden eli oikeammin sanottuna kananmunantuotannon teknillisessä ja taloudellisessa tasossa tapahtuneet muutokset lähinnä vuodesta 1949 lähtien. Vertailun vuoksi taulukkoihin on otettu mukaan myös ensimmäisen kirjanpitovuoden 1933 tuloksia.

Taulukossa 1 esitetään yleisiä teknillisiä tietoja. Kuten siitä ilmenee, on kirjanpitokanaloiden lukumäärä melkoisesti vaihdellut. Kun lisäksi otetaan huomioon, että kanalat eivät tietenkään ole olleet samoja koko ajanjaksona, niin tämä tietysti heikentää eri vuosien välisiä vertailuja. Toisaalta on erittäin ilahduttavana seikkana todettava, että kahtena viime kirjanpitovuonna kirjanpitokanaloita on ollut yli 30 , mikä lisää näiden vuosien tulosten edustavuutta. Taulukon toisessa pystysuorassa sarakkeessa on tietoja yritysten suuruudesta mitattuna täysikasvuisten kanojen lukumäärän perusteella. Tietynlaista suuntausta kanamäärän nousuun on todettavissa, kun verrataan 1950-luvun alkupuolta 1950-luvun loppuvuosiin. Varsin mielenkiintoista on todeta, miten keskituotokset ovat selvästi kohonneet. 1930-luvun alussa ja puolivälissä keskituotos kirjanpitokanaloissa oli yleensä 150 munan tasoa. Sodan jälkeen munantuotos on aivan ilmeisesti noussut, 
Taul. 1. Yleisiä teknillisiä tietoja Siipikarjanhoitajain Liiton kirjanpitokanaloista.

Table 1. General technical data obtained from Finnish poultry farms keeping accounts.

\begin{tabular}{|c|c|c|c|c|c|c|c|c|}
\hline \multirow{4}{*}{$\begin{array}{l}\text { Kp- } \\
\text { vuosi } \\
\text { Fiscal } \\
\text { year }\end{array}$} & \multirow{4}{*}{$\begin{array}{c}\text { Kana- } \\
\text { loita } \\
\text { Number } \\
\text { of } \\
\text { farms }\end{array}$} & \multirow{4}{*}{$\begin{array}{l}\text { Täysik. } \\
\text { kanoja } \\
\text { keskim. } \\
\text { Hens } \\
\text { per } \\
\text { farm }\end{array}$} & \multirow{4}{*}{$\begin{array}{c}\text { Keski- } \\
\text { tuotos } \\
\text { kpl } \\
\text { Eggs } \\
\text { per } \\
\text { hen }\end{array}$} & \multirow{4}{*}{$\begin{array}{c}\text { Nuoria } \\
\text { kanoja } \\
\% \\
\text { Pullets, } \\
\text { per- } \\
\text { centage }\end{array}$} & \multirow{4}{*}{$\begin{array}{c}\text { Karsittu } \\
\% \\
\text { Culling. } \\
\text { per- } \\
\text { centage }\end{array}$} & \multirow{4}{*}{$\begin{array}{c}\text { Kuol- } \\
\text { leita } \\
\% \\
\text { Mortality, } \\
\text { per- } \\
\text { centage }\end{array}$} & \multirow{3}{*}{\multicolumn{2}{|c|}{$\begin{array}{l}\text { Rehuyksiköitä } \\
\text { kanaa kohti } \\
\text { yht. kotoista } \\
\text { Feed units }{ }^{1} \\
\text { per hen }\end{array}$}} \\
\hline & & & & & & & & \\
\hline & & & & & & & & \\
\hline & & & & & & & sum & $\begin{array}{l}\text { home } \\
\text { grown }\end{array}$ \\
\hline 1933 & 25 & 334 & 152 & 52 & 36 & 5 & 37 & 12 \\
\hline 1949 & 13 & 190 & 174 & 53 & 10 & 15 & 39 & 28 \\
\hline 1950 & 20 & 151 & 180 & 51 & 33 & 15 & 40 & 25 \\
\hline 1951 & 15 & 155 & 188 & 50 & 31 & 15 & 40 & 20 \\
\hline 1952 & 15 & 171 & 187 & 49 & 37 & 15 & 41 & 21 \\
\hline 1953 & 14 & 161 & 187 & 46 & 29 & 14 & 41 & 17 \\
\hline 1954 & 16 & 233 & 187 & 59 & 40 & 19 & 42 & 13 \\
\hline 1955 & 14 & 244 & 201 & 55 & 22 & 20 & 43 & 11 \\
\hline 1956 & 13 & 230 & 189 & 52 & 40 & 17 & 43 & 10 \\
\hline 1957 & 17 & 230 & 197 & 59 & 27 & 18 & 43 & 12 \\
\hline 1958 & 32 & 236 & 198 & 53 & 29 & 18 & 42 & 11 \\
\hline 1959 & 32 & 261 & 199 & 56 & 42 & 19 & 41 & 11 \\
\hline
\end{tabular}

1 A feed unit is equivalent to approximately $1 \mathrm{~kg}$ or $2.2 \mathrm{lbs}$ of poultry feed (mash or grain).

ja jonkin verran pyöristäen voidaan sanoa, että se on 10 viime vuoden aikana noussut 25 munalla kanaa kohti, joten keskituotokset nykyisin ovat 200 munan vaiheilla, kun ne ennen sotaa olivat 150-160 munan paikkeilla. Munantuotannon kausivaihtelussa on sikäli tapahtunut muutos, että syys-marraskuun tuotos v. 1933 oli $17 \%$ kokonaistuotoksesta, vuonna $195019 \%$, mutta vuonna 1959 sitä vastoin $24 \%$. Selvää siirtymistä myöhäissyksyyn on niin ollen tapahtunut.

Kuolleisuus- ja karsintaprosentti on laskettu kirjanpitovuoden alkuinventaarion eläimistöstä. Mitään mainittavaa muutosta kanakannan uudistamisen nopeudessa ei näy tapahtuneen, koska nuorien kanojen osuus koko eläinmäärästä ei osoita mitään tyypillistä kehityssuuntaa. Voitaneen kuitenkin todeta, että karsinta näyttää olevan ankarampaa nykyisin kuin kymmenisen vuotta sitten. Eräs seikka, joka antaa aihetta huolestumiseen, on itsestään kuolleitten kanojen suhteellisen osuuden nousu. On ilmeistä, että kuolleisuusprosentit ovat nykyisin korkeammat kuin aikaisemmin. Erikoisesti asianlaita on näin, jos verrataan tilivuoden 1933 tuloksia viime vuosien tuloksiin. Tosin karsittujen ja kuolleiden välinen raja ei aina ole selvä, mutta kuolleisuusprosentin muutokset ovat kuitenkin niin huomattavat, että edellä mainittu toteamus kuolleisuuden lisääntymisestä pitänee paikkansa.

Taulukossa 1 esitetään lisäksi tietoja rehun käytöstä. On ymmärrettävää, että 1930-luvulla oli rehun kulutus kanaa kohti vähäisempää, koska tuotostasokin oli alempi. 1950-luvulla ja etenkin sen loppupuolella rehun käyttö on liikkunut $41 — 42$ rehuyksikön vaiheilla. Taulukosta käy myös varsin selvästi ilmi, miten 
kotoisten rehujen käyttö on 1950-luvulla vähentynyt. Kotoisilla rehuilla ymmärretään omalla maatilalla tuotettuja rehuja. Ostorehut saattavat sisältää sekä tuontirehuja että kotimaassa, mutta muualla kuin omalla tilalla tuotettuja rehuja.

Tuotannon tehokkuus kananmunien osalta voidaan ilmaista käytetyn rehuyksikkömäärän tai kuluneen työnmenekin tai muitten tuotantovälineitten käytön perusteella munakiloa kohti esitettynä. Taulukosta 2 ilmenee, että tuotannon tehokkuus on noussut, jos verrataan 1950-luvun viimeisiä vuosia saman vuosikymmenen alkuvuosiin ja 1930-luvun kirjanpitovuosiin. Työn tehokkuuden nousu johtuu sekä työnmenekin supistumisesta kanaa kohti että tuotoksen lisääntymi-

Taul. 2. Munantuotannon tehokkuutta ja taloudellisuutta osoittavia lukuja Siipikarjanhoitajain Liiton kirjanpitokanaloista.

Table 2. Economic and efficiency data from Finnish poultry farms keeping accounts.

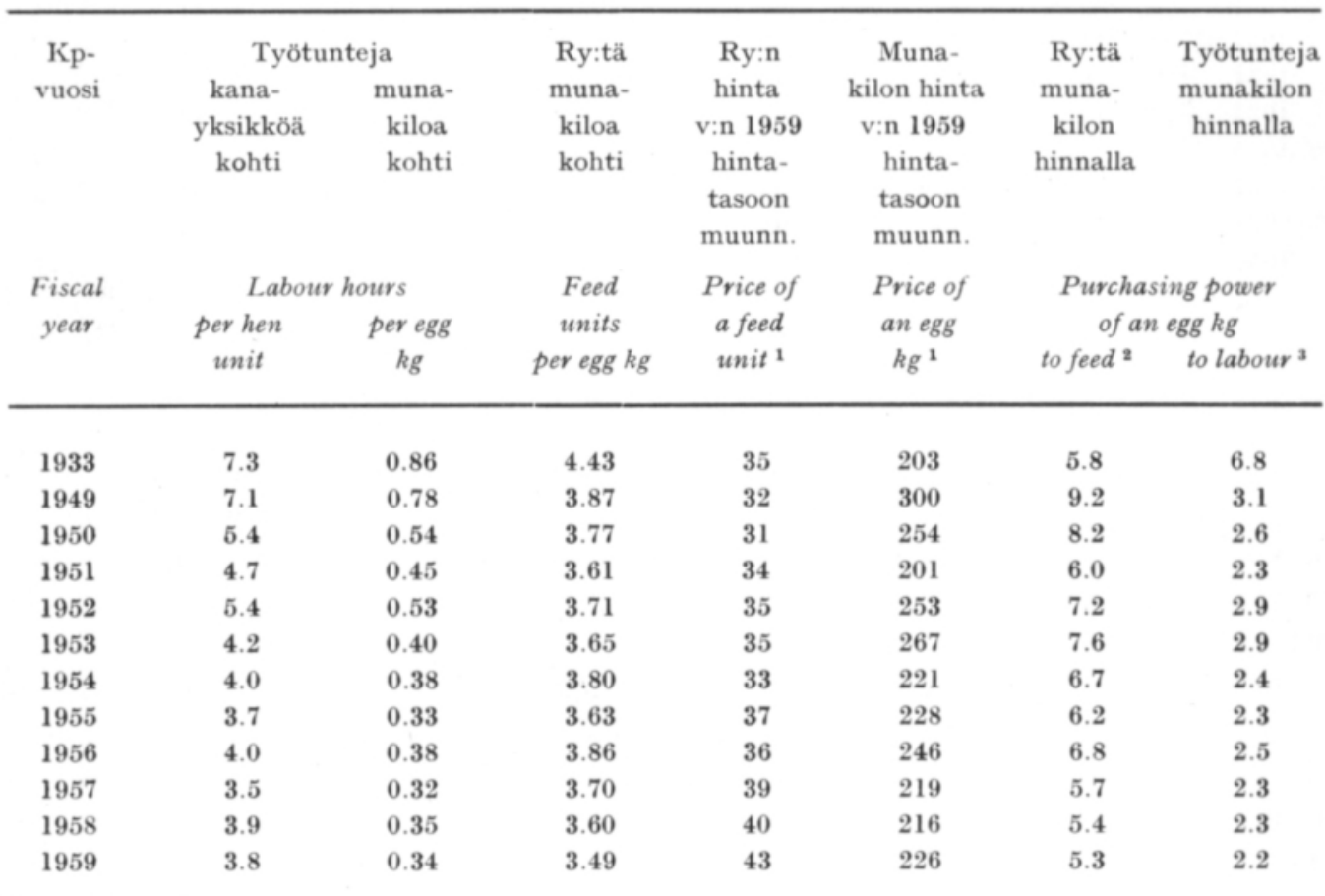

1 The prices expressed into Finnish marks are converted in accordance with the general wholesale price index of home market goods.

2 With purchasing power is understood how many kilograms of poultry feed one can buy with the producer price of one kg eggs.

3 With purchasing power is understood how many hours of labour one can buy with the producer price of one kg eggs.

sestä. Työnmenekki kanaa kohti oli vielä v. 19497.1 tuntia vuodessa, mutta viime vuosina se on ollut vajaat 4 tuntia. Taulukossa 2 esitetään myös eräitä kananmunantuotannon taloudellista kehitystä osoittavia numeroita. Jotta eri vuosien tulokset olisivat paremmin keskenään vertailukelpoisia, on hinnat ja muut rahal- 
liset suureet muunnettu vuoden 1959 hintatasoa vastaaviksi kotimarkkinatavarain tukkuhintayleisindeksin perusteella. Tosin tämä indeksi ei ehkä ole aivan oikea osoittamaan kananmunantuotannon kehitystä, mutta parempiakaan indeksisarjoja ei ole ollut käytettävissä.

Tarkasteltaessa ensinnäkin rehuyksikön hinnan vaihteluja on todettava, että ei vain nimellisesti, vaan myös reaalisesti rehujen hinnat ovat melkeinpä koko 1950-luvun aikana osoittaneet nousua. Erikoisesti näin on ollut asian laita viime vuosina. Sitä vastoin munien reaalinen hintataso on osoittanut laskua, joskin on huomattava, että kehitys ei ole aivan selvä ja että heilahteluja vuodesta toiseen on tapahtunut.

Munakilon ostovoima on selvästi laskenut. Tarkasteltaessa ensinnäkin munakilon ostovoimaa rehun hintaan verrattuna havaitaan, että ostovoima oli varsin hyvä vuosina $1949-1950$, mutta että se on vuodesta vuoteen heikentynyt. Vuosi 1951 oli kaikissa suhteissa poikkeuksellinen ja myös ostovoima oli silloin paljon heikompi kuin yleensä 1950-luvun alussa. On kuitenkin muistettava, että 1950-

Taul. 3. Kokonaistuoton ja tuotantokustannuksen kehitystä osoittavia lukuja. Luvut kanaa kohti mk:oina v:n 1959 hintatasoon muunnettuina tukkuhintayleisindeksin mukaan.

Table 3. Gross return and production costs per hen in Finnish marks on Finnish poultry farms keeping accounts. The figures are converted in accordance with the general wholesale price index of home market goods to the price level in 1959.

\begin{tabular}{|c|c|c|c|c|c|c|c|}
\hline \multirow{4}{*}{$\begin{array}{l}\text { Kp- } \\
\text { vuosi } \\
\text { Fiscal } \\
\text { year }\end{array}$} & \multirow{4}{*}{$\begin{array}{c}\text { Kokonais- } \\
\text { tuotto } \\
\mathrm{mk}\end{array}$} & \multirow{4}{*}{$\begin{array}{c}\text { Tuotanto- } \\
\text { kustannus } \\
\text { mk } \\
\text { Production } \\
\text { costs }\end{array}$} & \multicolumn{3}{|c|}{$\begin{array}{l}\text { Tuotantokustannuk- } \\
\text { sesta } \%: \text { na }\end{array}$} & \multirow{4}{*}{$\begin{array}{l}\text { Netto- } \\
\text { voitto } \\
\mathrm{mk}^{2} \\
\text { Net } \\
\text { profit }^{2}\end{array}$} & \multirow{4}{*}{$\begin{array}{c}\text { Perheen } \\
\text { saama } \\
\text { ylijäämä }{ }^{3} \\
\text { Family } \\
\text { income }^{3}\end{array}$} \\
\hline & & & $\begin{array}{l}\text { rehu- } 1 \\
\text { kust. }\end{array}$ & $\begin{array}{l}\text { työ- } \\
\text { kust. }\end{array}$ & $\begin{array}{l}\text { muu } \\
\text { kust. }\end{array}$ & & \\
\hline & & & \multicolumn{3}{|c|}{$\begin{array}{c}\text { Division of production } \\
\text { costs in percentage }\end{array}$} & & \\
\hline & & & feed $^{1}$ & labour & other & & \\
\hline 1933 & 2622 & 2174 & 62 & 13 & 25 & 448 & 883 \\
\hline 1949 & 3429 & 3000 & 46 & 27 & 27 & 428 & 1236 \\
\hline 1950 & 3030 & 2921 & 50 & 20 & 30 & 109 & 931 \\
\hline 1951 & 2263 & 2684 & 58 & 16 & 26 & -421 & 215 \\
\hline 1952 & 3038 & 2948 & 57 & 19 & 24 & 90 & 797 \\
\hline 1953 & 3169 & 2743 & 60 & 17 & 23 & 426 & 1056 \\
\hline 1954 & 2725 & 2757 & 60 & 15 & 25 & -32 & 586 \\
\hline 1955 & 2824 & 2947 & 62 & 14 & 24 & -123 & 467 \\
\hline 1956 & 3109 & 3072 & 60 & 15 & 25 & 37 & 627 \\
\hline 1957 & 2914 & 3031 & 65 & 14 & 21 & -117 & 421 \\
\hline 1958 & 2809 & 3054 & 64 & 14 & 22 & -245 & 293 \\
\hline 1959 & 2975 & 3211 & 65 & 14 & 21 & -236 & 340 \\
\hline
\end{tabular}

1 Täysik. kanat + poikaset. Adult hens + chicks.

2 Nettovoitto $=$ kokonaistuotto - tuotantokustannus. Net profit $=$ gross return less production costs.

s Perheen ylijäämä $=$ nettovoitto + korko + perheen työn arvo.

Family income $=$ net profit + interest + value of family labour. 
luvun muita alkuvuosia on pidettävä poikkeuksellisen edullisina. Munakilon ostovoimaa työn hintaan nähden tarkasteltaessa todetaan, että kun v. 1953 kanalan omistaja voi yhden munakilon hinnalla ostaa 6.8 työtuntia, ei sillä 1950-luvulla ole voitu ostaa edes puolta tästä määrästä; viime vuosina suhde on ollut niinkin epäedullinen, että yhden munakilon hinnalla on saanut vain $2.2-2.3$ työtuntia. On syytä mainita, että kirjanpitokanalat ovat yleensä saaneet keskitasoa korkeampia munanhintoja osaksi tuotteiden paremman laadun, osaksi myös sen vuoksi, että monet kanalat ovat myyneet munat suoraan kuluttajille.

Taulukossa 3 esitetään tietoja kanatalouden kannattavuudesta. Kokonaistuottoa ja tuotantokustannusta osoittavat luvut on muunnettu 1959:n hintatasoa vastaaviksi kotimarkkinatavarain tukkuhintayleisindeksin perusteella. Kokonaistuotto liikkui 1950-luvun alussa, poikkeusvuotta 1951 lukuun ottamatta, melko lähellä 3000 markkaa, saman kymmenluvun loppupuolella suunta on ollut aleneva. Kirjanpitovuosina 1933 ja 1938 oli kokonaistuotto huomattavasti alempi, mikä johtui kuitenkin suurelta osalta silloisesta alemmasta tuotostasosta. Tuotantokustannus on 1950-luvulla osoittanut jatkuvaa nousua ja ylittää huomattavasti 1930luvun kirjanpitovuosien tason. Tarkasteltaessa tuotantokustannuksen jakaantumista kustannuserien kesken, havaitaan selvästi, että rehukustannuksen osuus on nousemistaan noussut 1950-luvulla ja että se nykyisin on jopa korkeampi kuin 1930-luvulla. Toisaalta on työkustannuksen osuus laskemistaan laskenut ennen kaikkea siitä syystä, että työt on pystytty rationalisoimaan jatkuvasti, jopa nopeammassa tahdissa kuin työpalkat ovat kohonneet. Työkustannuksen pieni prosenttiosuus 1930-luvulla johtuu silloisesta alhaisesta palkkatasosta. Rehukustannuksen jatkuva nousu ja työkustannuksen aleneminen prosentteina laskettuna on siis selvin 1950-luvulla tapahtunut muutos tuotantokustannuksen koostumuksessa.

Kanatalouden kannattavuuden mittapuuna on käytetty sekä nettovoittoa että kanatalousylijäämää eli perheen saamaa ylijäämää kanaa kohti esitettynä. Nettovoitto on kokonaistuoton ja tuotantokustannuksen välinen ero, kun taas kanatalousylijäämä eli perheen saama ylijäämä saadaan siten, että kustannuksena ei oteta huomioon viljelijäperheen omaa työtä eikä myöskään korkokustannusta. Perheen ylijäämä osoittaa siis, minkä korvauksen kanatalous on pystynyt maksamaan yrittäjäperheen työlle ja yritykseen kiinnitetylle pääomalle. Sekä reaalinen nettovoitto että perheen reaalinen ylijäämä ovat 1950-luvun loppupuoliskolla selvästi alittaneet vastaavat kannattavuustulokset saman kymmenluvun alkupuoliskolla samoin kuin 1930-luvulla. Tämä asiantila johtuu munien hintatason alenemisesta. Munantuotoksessa tapahtunut nousu ei ole pystynyt tätä korvaamaan. Kanaa kohti laskettu kannattavuus on niin ollen heikentynyt.

Koska yrittäjän pyrkimyksenä viime kädessä on nimenomaan saada aikaan perheelle suuri ylijäämä yrityksestä kokonaisuudessaan eikä niinkään paljon kanaa kohti, hän on pyrkinyt kompensoimaan kanaa kohti lasketun kannattavuuden heikkenemisen lisäämällä kanamäärää, jotta yrityksen ylijäämä ei laskisi. Tämä käy ilmi taulukosta 4, joka selvästi osoittaa kanamäärien jatkuvan nousun kanalaa kohti. Taulukosta käy kuitenkin myös ilmi, että yrittäjät eivät ole edellä mainituissa pyrkimyksissään täysin onnistuneet. 
Taul. 4. Tietoja kanataloutta kohti lasketun perheen ylijäämän kehityksestä.

Table 4. Data indicating total family income from poultry husbandry per farm.

\begin{tabular}{ccc}
\hline $\begin{array}{c}\text { Kolmivuotiskausi } \\
\text { Triennial period }\end{array}$ & $\begin{array}{c}\text { Kanoja } \\
\text { Hens per farm }\end{array}$ & $\begin{array}{c}\text { Perheen ylijäämä mk } \\
\text { Family income mk }\end{array}$ \\
\hline $1949-51$ & 165 & 131010 \\
$1952-54$ & 188 & 152844 \\
$1955-57$ & 235 & 118675 \\
$\left.1958-59^{1}\right)$ & 249 & 78933
\end{tabular}

1) Kaksi vuotta. Two years only.

\title{
$P \ddot{a} \ddot{t}$ e l $m \ddot{a}$
}

Kirjoituksessa on esitetty eräitä Siipikarjanhoitajain Liiton kirjanpitotoiminnasta saatuja tuloksia. Nämä osoittavat selvästi, miten kanatalousala on nimenomaan 1950-luvulla teknillisesti katsoen ripeästi edistynyt Suomessa. Onkin ilmeistä, että kanatalousala on niitä tuotannonaloja maataloudessa, jossa teknillinen kehitys on ollut nopeinta. Tämä ehkä osaksi selittää myös sen tosiseikan, että munakilon ostovoiman heikentymisestä huolimatta Suomen kananmunantuotanto ei ole osoittanut mitään supistumisen merkkejä.

S U M M A R Y :

\section{TECHNICAL AND ECONOMIC DEVELOPMENT ON FINNISH POULTRY FARMS KEEPING ACCOUNTS}

N. Westermarck

\author{
Department of Agricultural Economics, University of Helsinki
}

Research work concerning the profitability of poultry farming and particularly of egg production, based on bookkeeping, was included in the programme of the Finnish Poultry Breeders' Association (Siipikarjanhoitajain Liitto) in the year 1932. The work has been confined to actual egg production farms which either buy, or hatch their chicks themselves, and which sell eggs but to no considerable degree breeding fowls.

General technical information is given in Table 1. As can be seen the number of bookkeeping poultry farms has fluctuated considerably. It is especially interesting to note how the average outputs have clearly increased. At the beginning and during the middle of the 30 's, the average output on bookkeeping poultry farms was, in general, on the 150-egg level. After the war egg production has perceptibly increased so, that during the past ten years the production has risen by approximately 25 eggs per hen, the average outputs at present being approximately 200 eggs. There has been a change in the seasonal egg production in that the September-November outputs in the year 1933 were 17 per cent 
of the total production, in 1950 they were 19 per cent, and by 1959 they had grown to be as much as 24 per cent. There has thus been a clear change over to late autumn production.

It may be noted that culling seems to be more stringent now than it was a decade or so ago. A matter which gives some cause for anxiety is the increase in the relative number of hens dying before culling. It is obvious that the present death percentages are higher than previously.

Table 1 gives, in addition, information about the consumption of feeds. It is understandable that during the 30 's the feed consumption per hen was less, since even the production level was lower. By home grown feed is to be understood feed produced on the farm in question. Purchased feeds might include imported feeds as well as feeds produced elsewhere in the country.

With reference to the production of eggs, the efficiency of the production can be gauged on the basis of the feed units used, the labour consumption, or on the basis of the use of other means of production per kilogram of eggs. Table 2 reveals that the efficiency of production has increased when comparing the situation during the last years of the 50's with the beginning of the same decade or with the financial years of the 30 's.

Table 2 also contains certain information relating to the development of the economics of egg production, or more correctly, certain figures connected with it. So that the results of various years might be more easily compared, prices and other monetary units have been converted to the 1959 price level on the basis of the general wholesale price index of home market goods.

Table 3 presents data regarding the profitability of poultry farming. Figures indicating the gross returns and the production costs have been converted to coincide with the 1959 price level on the basis of the general wholesale price index of home market goods.

The net profit as well as the family income per hen have been used as the measuring rod for the profitability of poultry farming. The net profit is the difference between the gross return and the production costs, whereas in computing the family income the family's own labour and interest costs are not regarded as costs. The family income thus indicates the compensation which poultry farming has been able to provide for the labour of the farmer and his family and for the capital invested in the enterprise. Both the net profit as well as the family income during the latter half of the 50 's have clearly remained below the corresponding profitability figures of the first half of the same decade as well as those of the 30 's. This situation arises from the declining price level of eggs. The rise in egg production has not provided adequate compensation and the calculated profitability per hen has clearly decreased.

Since in the last analysis it is the aim of the poultry farmer to obtain the greatest possible family income from his enterprise as a whole and not so much per hen, he has endeavoured to compensate the reduction in profitability per hen by increasing his stock so that the family income of the enterprise would not decline. This is revealed in Table 4, which clearly indicates a steady increase in the number of chickens per poultry farm. 